\title{
Roles of organizations in socialization of youth leaders in the occupied Palestinian territory (oPt) after Oslo
}

\author{
Abeer MUSLEH \\ Bethlehem University (Occupied Palestinian Territories). \\ abmusleh@gmail.com \\ Recibido: 25/10/2015. Revisado y aprobado para publicación: 22/12/2015
}

Para citar este artículo: Abeer Musleh (2015): "Roles of organizations in socialization of youth leaders in the occupied Palestinian territory (oPt) after Oslo", Revista de Estudios Internacionales Mediterráneos, 19, 91-111.

Para acceder a este artículo: http://dx.doi.org/10.15366/reim2015.19.006

\begin{abstract}
:
This paper aims at studying the socialization of young people through organizations in the oPt, and accordingly how would that impact the forms of engagement and leadership they pick. This paper utilizes multiple case study and institutional ethnography research methods, in which it compares three types of organizations. Through this paper we found that founders had the upper hand in organizations, and youth positions even in the highest forms of organizations was limited. Yet the highest the position of youth in the organization, the more engaged they are, and their leadership skills became more institutional. Interaction among founders and youth leaders are essential especially through mentorship. Mentorship played a very important role in all organizations in building the identity and capacity of the youth leaders.
\end{abstract}

\section{Key words}

organizations, engagement, leadership, Palestine, socialization, Youth

\section{Resumen:}

Este artículo estudia la socialización de los jóvenes a través de la participación en organizaciones sociales en los territorios palestinos ocupados, haciendo particular hincapié en cómo influyen los distintos tipos de participación y de liderazgo que adoptan. Se utilizan métodos de investigación propios del "múltiples casos de estudio" y de la "etnografía institucional", para así comparar tres tipos de organizaciones. Mediante este trabajo, comprobamos que los fundadores de las organizaciones seguían ejerciendo el poder en las organizaciones, y que la posición de los jóvenes, 
incluso en las más complejas formas de organización, se enfrentaba a serios límites. Así, cuanto más alta es la posición de los jóvenes en la organización, más intenso será su compromiso con ésta, y más institucional se convertirán sus recursos de liderazgo. La interacción entre los fundadores y los líderes jóvenes son esenciales especialmente a través de la tutela de los mentores. El mentor juega un papel muy importante en todas las organizaciones en la construcción de la identidad y la capacidad de los jóvenes líderes.

\author{
Palabras claves: \\ Organizaciones, participación, liderazgo, Palestina, socialización, Juventud
}

\title{
Introduction
}

The signing of Oslo Accord in 1993, with the start of a state-building process and the focus on development, marked a moment of transformation in the Palestinian society. As part of this change the Palestinian political and institutional field moved from collectively working against occupation, to the process of building state and development. Amongst this transition the image of youth as activist was transformed into that of youth as victim of the Palestinian-Israeli conflict (Collins, 2004; Kanaana, 1993). Palestinian youth moved from being active participants in the political process, in which they were an asset to Palestinian society, a target group that needs to be empowered (Rahal, 2006).

This shift in the way youth were perceived took place in conjunction with the emergence of a large number of organizations working with youth. According to Rabah (2009), 74 percent of organizations working with youth in the occupied Palestinian territory (oPt) were established after the year 2000, with two peaks, one in the year 2000 and the other in 2004. Still, this increase in the number of organizations did not lead to an increase in youth participation in local governance and political parties, nor did it empower youth to hold decision making positions. On the contrary, youth participation levels were seen to be low (Rahal, 2010a, 2009, 2010b).

These days, despite all the interventions with young people by different youth organizations and developmental organizations, youth are facing major challenges at different levels, such as access to decision making positions in governmental organizations, NGOs, and political parties, and their economic situation in comparison to other population groups. In regard to economic challenges, the rate of unemployment averages about 40 percent for the youth between the age of 25-34 years old, with 30.1 percent for males and 47.3 for females, while the unemployment rate among people 35-44 is 16.1 percent for males and 11.7 for females (PCBS, Annual report, 2011). Articles 18 and 45 of the local electoral law limits the opportunity of youth to reach decision making positions whether at the local level or on the legislative council (Palestinian Parliament). Although both laws recognize that youth at age 18 can vote, they limit their right to nominate themselves to local and legislative councils. Youth have to be 25 years of age to be nominated to the local councils and 28 to be nominated to legislative council (Authority, 2005, 2007).

This paradoxical status of youth in Palestinian society raises concerns in regard to the extent to which they are being involved in the democratic nation-building process. Youth play an essential role in developing their societies. In the Palestinian context, where the society is trying to sustain 
itself and progress under occupation, the role of youth, who form 27 percent of the population, becomes even more critical. In recent history, Palestinian youth played an important role in shaping sociopolitical life. Not only did they form and participate in various organizations and political parties that mobilized and supported Palestinian society, they also played an essential role in introducing new forms of engagement. Representation and access to decision making for various population groups can support a development process that is based on equity and consideration for the needs of all.

This research aims to explore the socialization process of young people through organizations into civic engagement. Through understanding youth socialization we can learn more about the roles that they were prepared to take. And this eventually can help answering why youth were not highly involved in mobilization activities during and post the Arab spring period. To explain socialization this paper will look into the entry point of engagement of young leaders, relation with other age cohorts, youth position in organizations.

Over the period of three decades, the organizational structure that worked with youth varied and included from grassroots mobilization structures, student unions, political parties, charitable organizations, development NGOs, youth-led organizations, social movement organizations, and religious organizations. These organizational structures and models of work varied based on the historical period in which they were established. Within this study I am going to consider, first, the Youth Association, a youth development organization that was established by a political party; second, Engage, which is a youth led organization that was established after the Oslo Accord by a donor organization; and third, the Youth Rights Activation, another youth development organization that focuses on youth journalism in the post-Oslo period. The distinction between these three organizations lies in the leaders who established them, as they were established by leaders from different age cohorts.

\section{Literature review}

This research looks mainly into political socialization of youth as the umbrella for analysis, yet it looks into leadership literature when explaining the roles played by young people within the organizations.

Political socialization has been studying how it would be possible to get youth to become active citizens. Socialization theory shows that the process starts from the early stages of the human being. It starts from early childhood with the family influence on its members. Other factors play an important role in socialization of youth such as schools, religious organizations, development organizations, race, gender and historical period. Traditional theories of socialization consider young people as recipients for the concepts and not reasoning the, yet Rosenberg (1988) pointed out the active use of reasoning in forming political concepts. Further, as societies are complex it won't be easy just to pass a message homogeneously among various groups. Younis et al. (2002) notices that adults are not always in a position to hand youth a clear view of what society should be. Further, as youth get involved in working on the ground they get involved in habitual practices. Verba, Scholozman and Brady (1995) looked onto habitual practices as essential factor in determining adult participation in democratic process. 
New literature about socialization looks beyond the internalization of knowledge to a process that includes cognitive activity; it reflects the complexity of the society through density of knowledge. Flanagan emphasize the influence of national context on youth's interpretation of the social contract that they are expected to adopt. This is of importance especially when studying the Palestinian context.

The literature on political generations has emphasized the impact of political opportunity on shaping the collective identities of generational members based on their lived experience, and the effect on generations' socialization and identification processes (McAdam, 1992). This will help in understanding how the transitions in the environment can impact individuals and organizations in terms of their position, mobilization structure, identity, and framing (Meyer, 2003; Meyer \& Minkoff, 2004). In youth engagement, political opportunity is looked at with the existence of different institutional structures that facilitate youth participation; with the role of the environment in the political socialization of youth and in facilitating the forms of their engagement. Yet it does not look at how the youth interact with the environment as much. Further, when exploring the change in youth political socialization it is of importance to look into leadership formation. Leaders have an important role in creating institutions (Hardy \& Maguire, 2008), strengthening them (DiMaggio \& Powell, 1983) and changing them (Greenwood, Suddaby \& Hinings, 2002). Marvin Washington and colleagues recognize the role of leaders in transforming organizations to institutions, through building a character, vision, and values of the organization. They underline three roles for leaders of institutions: Internal uniformity, overcome external enemies, development of supporting mechanisms. The institutionalization process is related to the interest of organizations to maintain its existence (Washington, Boal, \& Davis, 2008). The leaders are considered critical as they mobilize resources, create and recognize opportunities, inspire commitment, and frame demands, encourage participation, and create links with other structures (Klandermans, 1989; Morris \& Staggenborg, 2007).

Morris and Staggenborg (2007) identify different factors that impact members' ability to become leaders such as gender, education, previous involvements, and experiences. These factors are important to recognize, especially that they show the power dynamics and who is allowed to reach to which level of decision making in movements and organizations. In addition, leaders with different background and experiences make different strategic choices. The above distinctions across types and roles of leaders inform this dissertation research. The comparison across leaders from different age cohorts, we can develop a perspective not only about changes in the leaders' perspectives, but also, the role of structures in preparing which type of leaders.

Literature about youth development focuses on building the future leaders (Carole, 2006; Gambone, Hanh Cao, Lewis-Charp, Sipe, \& Lacoe, 2006). Engaging them in decision making within organizations was one of the essential factors considered, their relation with adults through youth-adult partnership was considered important to develop their skills and to start a dialogue with the previous generations. A youth development approach for leadership focuses on providing youth with a voice within organizational structures, but through socializing them into the existing structures, the skills are directed toward program management. In contrast, Youth led organizing looks more into youth as mobilizers within an understanding of social injustice and change for the existing structures. Still the two sets of literature do not interact with each other. In this research through comparing the different leaders and how they emerged, it will be possible to look at what type of leaders youth organizations are preparing, and do these types of leaders vary based on the role they are playing in the organization or not. 


\section{Methodology}

This paper is based on a multiple case study approach that is drawing comparisons among types of organizations in the youth field in the oPt. According to Robert Yin $(2012$, p.4) the case study approach allows "investigators to focus on a case and retain a holistic and real-world perspective such as in studying individual life cycles, small group behavior, organizational and managerial processes". The use of the case study approach in studying youth engagement and development has been shown to provide in-depth understanding of programs and organizations, how youth political socialization takes place (Yates, 1999), how contexts impact the forms of engagement (Yates, 1999; Youniss et al., 2002), and about the different models of youth organizations (Zeldin, Petrokubi, \& MacNeil, 2008; Zimmerman, 2007). The organizations selected represent the structures established by different generations. Accordingly, the comparison across the organizations allows us to look into the relation between the experience of youth and how it impacts their identity, their form of engagement, and the skills they acquire. It is about explaining how organizations affect the youth perception about the world around them, themselves, and their role as actors.

The data for this research was collected between December2008- and May 2012. The selected organizations ensured that they had many youth cohorts in them and that it will represent the changes in the youth field in the oPt. The experience of members of an age cohort is decided by the historical point of entry, in which the shared experience they go through together shapes their identities and worldviews. Organizations not only represent the age cohort that established them, but they are also a place of interactions between earlier and later age cohorts and a place in which the identities and skills of new leaders are formed. Different age cohorts have different worldviews and accordingly can impact the types of organizations and their structures differently, but at the same time, people's worldviews can be shaped by the organizations they are part of. Ultimately, the comparison across organization allows us also to draw comparisons across different age cohorts, and how their experience shaped and was shaped by a changing field of Youth.

The type of an organization and the age of the founder of each organization was essential in selecting the organization. First, the organizations represent three different types of organizations: 1) youth development organizations established from political affiliations, 2) youth development organizations established after Oslo, and 3) youth-led organizations. Second, although the selected organizations were all established within the span of six years from 1992 to 1997 the organizations were each founded by individuals belonging to different age cohorts, which then shaped the identities and experiences of other age cohorts. The research covers five age cohorts, defined by when the members started their engagement. The youth starting age varied between 13-22 Years, divided as follows: Voluntary community work (1978-1987), the First Intifada period (1987-1993), Post Oslo Period (1994-2000), the Second Intifada period (2001-2005), Division Era (2006-2012). Each of those periods represents a different sociopolitical context, which shaped the forms, culture, and venues of engagement, and accordingly the roles and skills of youth leaders varied among the various cohorts. 
The organizations selected for this study were selected for the following: Youth Association (YA) was the only Youth Development organization that was established by a political party; the organization was also selected because it was one of the oldest organizations established in the field of youth. In addition, its founder represents an age cohort that was different from the other two case studies. Engage was the only youth-led organization in the oPt that works on a national level, and it was one of the leading organizations in the field of youth. The Youth Rights and Activation organization (YRA) was chosen as the youth development organization established after Oslo. Although there were other organizations established during the same period, YRA had the most developed structure as a youth development organization.

The selection for individual participants was made in a way that ensured the representation of all age cohorts within an organization. The positions and roles played by the interviewees selected also allowed me to learn about how things were done in the organization. Further, to be able to analyze the impact of the various factors on organizations and leaders, it was important to interview individuals who were knowledgeable about the context but independent from the three organizations. Selection criteria for interviewees included gender, age cohort, position, role, and length of tenure with the organization, whether as a volunteer or member of the staff member. In addition, [some] interviewees were chosen if they had been recognized for important contributions to the organization by other staff members. Previous and current volunteers and staff were recruited to participate in the research, especially if they were mentioned by other interviewee as key people in the organization.

Sample selection for document and reports was based on the periods that the organization passed, and representation for major programs, in addition to cover all major reports published about the field of youth: the content analysis, all reports, I had access to, were included in the analysis.

\section{Results and discussion}

The comparison across organizations showed many factors that shaped the youth engagement culture and forms. These results are similar to factors discussed in both youth development literature under political socialization literature, and within political generations' literature. Context when starting engagement, organization structure and position of youth in the organization, type of programs, and interaction across age cohorts all proved to be important factors for shaping the identity and style of youth leaders.

\section{Entry point of engagement and shaping the worldview}

Not only the organizations are a place that shapes youth identity and space of engagement, but also it is a presentation of the founders' identity and believes (Manheim, 1952). 
Figure 1: Comparison across organizations founders

\begin{tabular}{|l|l|l|l|}
\hline & Youth Association & Youth Rights Activation & \multicolumn{1}{|c|}{ Engage } \\
\hline $\begin{array}{l}\text { Year started } \\
\text { engagement }\end{array}$ & \multicolumn{1}{|c|}{1975} & 1995 & \\
\hline Affiliation & $\begin{array}{l}\text { Grassroots n structure } \\
\text { Student unions, Political } \\
\text { party, NGO, Ministry of } \\
\text { Professional newspaper. } \\
\text { NGO } \\
\text { Youth and sports }\end{array}$ & $\begin{array}{l}\text { Foreign education } \\
\text { Community mobilizer }\end{array}$ & $\begin{array}{l}\text { Student union, Donors } \\
\text { NGOs, education }\end{array}$ \\
\hline Skills & $\begin{array}{l}\text { Grassroots, small donors, } \\
\text { political leadership }\end{array}$ & $\begin{array}{l}\text { Donors, NGOs, journalism } \\
\text { institutions }\end{array}$ & $\begin{array}{l}\text { Donors, NGOs, Decision makers, } \\
\text { political parties }\end{array}$ \\
\hline Network
\end{tabular}

When looking at the experiences of the founders of the organizations in figure (1) we notice that they form three age cohorts with different experiences. Founders of the organizations had different affiliations, skills, and networks. Comparing the three founders it is noticed that there is a less influence for political parties and increase for professional organizations affiliations and involvement as time passes. More professional structures and professional identity started to emerge as seen with both founders of YRA and Engage. With such change the leadership skills they developed varied from one age cohort to another. Based on the interviews conducted with the founder of YA one of the main affiliations that he mentioned was being part of many grassroots structures that mostly affiliated with the political party, and the political party (Mohamad, 2011). Yet in an era where political affiliation was the most dominant, the founder identity and models of intervention was towards serving that direction. Yet with the founder of Engage, although he was exposed to the grassroots structures and political parties yet he was not highly investing in it. Engage main commitment was in the NGO and donors organizations. As a result, he had a different network and space that shaped his identity, culture, and style of engagement. The period in which both of YA and Engage started was characterized with a high community collective engagement, a high oppression by the Israeli occupation for the people, and youth were the front line for the confrontation with the occupation, and they had an important role to play in ensuring the steadfastness of the Palestinian society. Political parties were forbidden by the Israeli occupation and accordingly the grassroots structures where the network in which the political parties reached to the community. Further, NGOs emerging were also considered as part of the national movement for liberation (Hammami, 2000; Jarrar, 2005; Hilal, 1998). 
On the other hand the founder of YRA involvement in organizations was through professional organizations and was never engaged in a political party or a grassroots structure, in addition to being exposed to foreign education which impacted her ability to communicate with donors later and receive resources. When we look at the organizations established by the three founders, it was noticed that the type of activities, organizational identity, and leadership style varied to reflect each leader experience of previous engagements.

Figure 2: Comparison across First Cohort of Youth Leaders

\begin{tabular}{|l|l|l|l|}
\hline & Youth Association & Youth Rights Activation & Engage \\
\hline $\begin{array}{l}\text { Year started } \\
\text { Engagement }\end{array}$ & \multicolumn{1}{|c|}{1994} & 1999 & 1999 \\
\hline Current Role & $\begin{array}{l}\text { Community center } \\
\text { manager }\end{array}$ & Unit Coordinator & Director \\
\hline Affiliations & $\begin{array}{l}\text { Politically affiliated, } \\
\text { NGOs }\end{array}$ & NGOs & NGOs \\
\hline Skills & Community mobilizer & $\begin{array}{l}\text { Management, Journalism } \\
\text { and media, writing reports, } \\
\text { trainer }\end{array}$ & $\begin{array}{l}\text { Managerial skills, } \\
\text { writing, fundraising. }\end{array}$ \\
\hline Network & Party related \& CBOs & NGOs, CBOs & $\begin{array}{l}\text { NGOs, } \\
\text { Governmental officials, political } \\
\text { parties leaders }\end{array}$ \\
\hline
\end{tabular}

As for the first cohort of youth leaders, as observed in table (2), we notice in the three organizations that they started their engagement post Oslo period. In which the political parties and grassroots organizations had less power in leading the Palestinian society. During this period political parties were replaced with Professional NGOs, yet these NGOs lost their wide base of constituencies (Hammami, 2000; Jad, 2007; Hilal, 2010; Jarrar, 2005). NGOs became highly donors' dependent, and work on specific sectors; concepts of development, empowerment, and working with sectors instead of whole community became the norm (Jad, 2004; Hammami, 2000). Youth turned from being the nation protectors (Collins, 2004) to another development sector (Jad, 2007) that needs to be empowered. Examining the starting point of the youth leaders, it is noticed that their main form of engagement available was through NGOs, and accordingly it is the most important structure that shaped their identity, culture and type of engagement. Being as part of an organization the program cycle approach starts to emerge, youth are being selected as a specific group to empower. The language used about working with youth was about empowering and developing youth, which is different than the previous phase when the steadfastness of the Palestinian society was important.

For example, the cohort of youth leaders at Engage, decided to adopt the approach of funded programs when became responsible for managing the organization. Although the youth leaders were pioneers in initiating initiatives that depends on volunteers in their local communities and organizations, they duplicated the structure familiar for them which is an NGO. Knowing that they are connected to financial resources through their founder, they also adopted the same standards of administrative and financial systems as the UN agency. 


\title{
Type of the organization and socialization type (perspectives, skills)
}

In this section I will look at how the organization type and values provided youth with a culture of engagement, role, relation with community, and leadership skills. The youth organization's type is of importance as it sets the space provided for youth engagement, identity, networks provided for youth and eventually the capabilities they will develop. Socialization of youth through organizations mainly takes place through the habitual processes in which the young people pass through (Verba, Schlozman \& Brady, 1995). Organizations provide youth with access to networks and resources, and expose them to specific practices through leadership (Delgado and Staples, 2007).

At the YA, which is a politically affiliated and a grassroots organization, the organization interventions were more directed towards local community empowerment and development. As political parties try to replicate itself in the structures it creates so it can ensure that it spreads its enhance its presence (Hilal, 1998). YA used two tools to do so: selecting the core group of youth leaders from affiliated young party members, and to base its work on volunteers and other CBOs in the local community (Mohamad, 2011). Accordingly the youth selected in principal to work with join the organizations were either politically affiliated to the party, or the party was interested in recruiting them. The relation between the founder and the youth leader reflected the party hierarchy in which they shared. Youth leaders were not appointed at high level positions in the organization, although they played an important role at the street level implementation. The youth leaders were the ones who run the operations and programs in the local level. As they were politically affiliated they shared the same set of values, as party members they felt that they were responsible for recruiting new members to the party. Mohamad (2011) describes in his own words the time when he joined Youth Association:

\begin{abstract}
"I joined the party when I was 14 years old, 20 years ago. At that time our local council was so weak and it did not have money to cover its expenses. The local governance situation was bad; there was no one to provide the services. I was raised in a leftist family; I participated in a community work camp that took place in Nazareth. Parties were the structures that were addressing the needs of the community through community work and compensating for the lack of services provided by the councils. After that the political parties started to establish organizations. In 1994 the party established the youth community center in my village as part of Youth Association the organization; we renovated an old house in the village as our community center for Youth Association ".
\end{abstract}

This quote shows that Mohamad had a long-time personal commitment to the party. The fact that he was so rooted in the party may have been an essential factor of his selection. It is of importance to mention that Mohamad is still affiliated with the party, and he is still an employee of Youth Association. As discussed by Delgado and Staples (2007) the selection of young leaders is crucial, especially at the point of the establishment of a new structure. Not only it is needed to ensure that they will continue in the organization for some time, but it is also essential to develop the capabilities to inspire, mentor, and mobilize other young people. In this case, the party selection for the youth community centers was of young people that party leadership observed before within the base of their affiliates. They knew that, as members who had been committed 
since they were 13 years old, their feelings of belonging and commitment to the party were high. Their basic skills as leaders and reputation among their colleagues were tested (Reyad, 2011); in addition they lived in the same community that the youth community center was serving, which provided them with the knowledge about the sociopolitical culture of the site (Ala, 2011). Those factors made the selected youth good candidates. Further, YA programs focused on meeting not only the needs of young people but also the community around them. Accordingly they needed to become a recognized actor within their local community; the youth center was not to turn down any community member who reached for its support. This provided the YA with legitimacy at the local community, and turned the youth into community organizers where they learned to recognize the challenges of the community and try to work collectively with other actors to make the change in the local community they live in. As part of cooperation it's noticed that they worked with the local women committee to provide support for students and women to have educational and income generating activities. The youth at YA did not have high skills in program management, but they were able to secure community participation, negotiate various issues in the local community and be considered a community resource.

On the other hand, YRA a youth development organizations working through media had another perspective for working with youth. YRA focused its work with young people on developing their skills and capacities as journalists. According to their founder they wanted to provide youth with a space to express themselves through media (Mona, 2011). YRA targeted youth at schools and universities, accordingly the age group selected immediately led to a division of adults and youth based on age. Further, the organization model was more dependent on paid staff rather than volunteers which made the upper hand in decisions to be for staff members. Although YRA provided youth with space to participate in editing the newspaper, yet they ensured that it will be overlooked by one of the adult staff members. The organization programs reflected a model of youth development that reinforced to a certain extent youth adult partnership. Youth adult partnership is one concept of youth development literature which focus on the assets brought by both parties and the importance of them to work together, in which the staff members will work with young people on writing their reports, facilitate their relation with organizations, and work together as part of the editorial board (Mutaz, 2011).

The organization identity as a youth media organization shaped the form of engagement of young people joining the organization. The main programs of the organization were media programs; a newspaper and a TV program, and community development based on advocacy. YRA targeted as its leaders youth in the universities mainly studying journalism and in some cases social sciences. One of the major selection criteria for youth was their education to be in fields of media and social sciences. This by itself directed youth engagement into specific directions of work. The organization's programs of community intervention was based on having organization staff, middle management of the organization who are the first cohort of youth leaders, to go into the community and work with a group of youth on specific issues. The work was temporary, not based on being an organizer from the community, it worked on developing specific skills for youth through training workshops, and minimal mentorship.

At YRA the youth leaders were more of organizational leaders rather than community organizers as seen at YA. This is related to the fact that they used to enter to a community as part of a program that they would implement. They were not based in a community center as YA in which they would be part of a larger community collective effort for change. The organizational value also was related to enhance youth civic learning, yet they aimed at not challenging the systems 
managing the field, they tried to work around it to ensure the minimum challenge they would face. As Ala (2011) mentioned,

"We knew that not everyone will be happy about our work. We tried not to not to have direct confrontation, for example, we will not talk with young people about the issue of hijab directly, but through journalism we ask them to look at the various opinions that are tackling the issue, the opinions that are supporting or opposing. As journalist we have to present both sides, we don 't favor one side over the other".

Looking at what Ala said, it raises many questions about the culture in which youth are socialized towards. The data collected in this paper also showed that the youth as holding middle management position, they are aware about the limitations facing the organization to secure resources and pressure from larger environment. Ensuring the organization position and sustainability, made them stuck in a process of program management and reporting for donors; which is different than skills obtained by youth at YA as community leaders. One of the main concerns of this model of youth development as discussed by Watts and Flanagan (2007) is that it is not pushing the boundaries that keep youth in an inferior position. To change youth status it needs more than just building their capacity as individual leaders, we need to look at the systems that hinder them from taking an active position.

As for Engage, as a youth led organization, youth were encouraged to come up with their own initiatives to implement. Yet, As it was originally supported by the United Nations Development Program (UNDP), even if it's a youth led structure, Engage perceived its role as an organization that will work on enhancing youth led activities and to affect policies that impact the youth position in the field, and accordingly its programs were developed in such direction. As a youth led organization the organization had a youth staff, which was mentored by the founder for about two years to play the various roles of the organization high and mid management. Further, the type of programs in which it worked with were directed to youth-to-youth learning, and employment, policies, and support of youth initiatives.

The organization as affiliated with the UN had as part of its board members international organizations representatives. Engage also ensured that its governance regulations are following the same system of the UN. As a result, Engage ensured that it is considered accountable for donor organizations, and as a youth led considered the representative for young people. Accordingly that means being able to meet the deadline set by the donors, not to say no for any donor organization approaching them, and provided more power to the director general and the chair of its board of trustees. With that Engage, alienated the youth who were working without donors, and who were interested in the process. Engage, programs again focused on a specific duration that was assigned by funding, and the major approach of work was about working with individual youth through various workshops and training. Building a youth collective identity and sustainability in the local community did not take place. Youth leaders who form the management level are excellent in promoting themselves to the community and policymakers, for sure their administrative skills -after reading their reports and publications- present a very high quality of knowing the language that should be used and a good ability to mobilize human resources for its advantage. Still its youth leaders were mainly socialized to be both institutional and organizational leaders in the organization and not community organizers. 


\section{Relation across age cohorts: position, mentorship, strategy of building the capacity of youth}

The relation across age cohorts was defined by the mentorship relation between them and the position in which young people occupied in the organization. It is important to note that in the three organizations under study mentorship was considered essential for shaping the skills and identity of the youth leaders. Further, to affect not only the skills that the youth had, but also their ability to influence the organization's decisions.

\section{Mentorship}

The founders' identity, background, and history of engagement provided each one of them with an accountability and dominant position in relation to the later youth leaders joining the organization, especially the first age cohort of youth leaders. According to first age cohorts of the three organizations under study, the relation between founders and first age cohorts of leaders was built on mentoring relationship (Reyad, 2011). Youth leaders at YA indicated that the history of their founder in political and community engagement was major factor in why they take into consideration his word (Mohamad, 2011 ). The founder seniority in the political party was reflected in the relation between youth and the founder especially that he was highly ranked in the political party. This was reflected with the limited willingness for young people to challenge the founder approach of work and interventions. The same issue was reflected in the other two organizations as the founder played an important role in establishing the organization, ensure its sustainability, and mentoring the young people and support them to get where they are at the current moment.

This is similar to what is discussed by Mische (2008) about leaders' strategies, and how they are a result of the leaders' previous experiences and the organizations' previous experience. With such recognition, and being the main mentors that worked with the initial groups of youth leaders, their position in the organization became essential. According to Washington, Boal and Davis (2008), leaders play an important role in framing an organization's work, building its culture, and facilitate its access to resources and coalitions. The interaction across former and later age cohorts takes place within the organizations, and a negotiation process on whose discourse is to dominate takes place (Klatch, 1999). Further, founders were considered not only to have access to resources whether financial, cultural, or moral, but also to own and control the resources through their networks and experience.

An important factor that made the young people consider the founders as their mentors was the one-to-one communication they had when they started their engagement. The sense of recognition by young people for the founders was not related only to what they invested in the organization only, but also part of a personal recognition for where they feel they stand at the moment (Ala, 2011; Mohamad, 2011; Mona, 2011). Camino and Zeldin (2002) introduce the importance of mentorship in the development of young people. The impact of adults on the healthy development of young people is crucial as they provide support, teach youth specific skills and knowledge, and help them to reach a specific objective (Freedman, 1993). According to Rola (2011), a current staff member who started as a volunteer with the organization when she was 13 years old: 
"We received all types of support we needed to write our articles. After the writing workshop the staff will help us pick the topics we want to write about, facilitated for us the meetings with people if needed, and in some cases even write the article together, we were supported at each step as we needed."

The above quote shows an interaction within an organization that is more on a horizontal structure, as a result of small size of the organization with a limited number of volunteers and clear task to accomplish. Youth in this structure managed to have a larger role in decision making process in the organization.

The youth leaders participating in the three organizations all started their engagement in the post Oslo period, in which most of them were only involved in one form of institutional structure which is NGO. This varied from the founders' generation in which they were affiliated in many structures such as political parties, student unions, and NGOs. For first cohort of youth leaders this was the most important experience they had. It is different than the founders who found many role models to provide them support, or where they could accumulate experience through their multiple affiliations. Yet, mentorship became less as organizations expanded their work. The youth joining the organizations at later stages were mainly developed through training, experience and mentorship they received in the organization (Ala, 2011;Rola, 2011, Mona, 2011).

Training youth and ensuring that they had the skills needed to play their role varied from one stage to another in the life of the three organizations. It is noticed that mentorship was an important component of the way first cohort of youth leaders were trained in the three organizations understudy. The one-to-one mentorship was combined with a practical experience needed to fulfil specific positions, or implement program activities.

One approach that was utilized by the three organizations is to form a core group of leaders that will be trained to take the lead of the organization work afterwards. For example, at Engage, they formed a core group of 15 young people in which they worked with them on running the day to do work of the organization. The same core group became the organization staff and management member, and members of the general assembly. Close mentorship was provided for the 15 young people over the period of 2 years, they were trained on how to run programs, networking, and mobilization of resources. As the youth were based in middle and higher management they had to be familiar with issues of planning, and fundraising. The core group of young people at YA had other skills to acquire as a community organization. YA core group of young people had to work on developing their local networks, and support from other community groups.

Despite the recognition of the importance of such approach from the first youth leaders, yet they did not use it with other young people who joined the organization. Capacity building for later young people was done through training in workshops. Later youth joining the organization participation was limited into joining the activities of programs. This by itself limited the participation of young people in the decision making, and as a result the power of decision making became concentrated with the founders and the first cohort of young leaders. The intervention of the organization moved from a youth led model of interventions towards a positive youth development model. In which youth are targeted to improve their skills as individuals, to ensure 
that they will turn to be good citizens, yet their participation is limited to learning what their needs are and implementing the activities.

As the organizations' work expanded in locations and numbers, the time needed to be spent in mentorship in the three organizations was limited by the organization staff, whether they are first cohorts of young leaders or founders. As a result, the new youth joining the organization did not have similar opportunity to develop their capabilities in leadership. The first cohort of young people was part of the establishment of the organization at that stage the organizations was still not that institutionalized, smaller in size, working with smaller number of youth. This ensured a strong connection between youth themselves, one-to-one relationship between youth and adults, and less worried about its sustainability. All these factors allowed young people to experiment and try to work through different approaches without being worried about funding and sustainability. When part of the system as staff the first cohort of youth expressed their concern that this became impossible and accordingly they had to work based on programs plans. In the words of Amal (2011):

\footnotetext{
"When we volunteered at Engage, we had our own initiative to lead, yet still as a UNDP affiliated organization we did not have to think about reports, donors, fundraising, etc... We only had to work on how to implement our initiative and how to make it successful. This allowed us to experiment and try different things. Yet when we held management positions we started worrying about salaries, donors, finishing programs on time, and accountability. With this we cannot experiment and try new things the way we want. Unless we ensure that the youth leader has the skills needed they will not be given the responsibility”.
}

In the previous quote we can see how the first cohort of young leaders became a reproducer for the system of NGO dependency on donors. This system decreases their ability to innovate and to develop their capabilities in the youth development sector.

\section{Position and roles played by youth}

In the three cases understudy, the type of the organization did not impact the division of roles between founders and youth leaders. Organizations main decisions and power were concentrated in the hands of the founders. First cohort of young leaders had control on the second line of management in the three organizations, with more space provided for youth at Engage as a youth led organization (Delgado and Staples, 2007). As for new comer youth, it is noticed that they don't have a strong position in their organization, they are mainly a target group for the organizations activity. In the three organizations, youth were trained to become organizational leaders and not institutional leaders.

The difference in the experience was related to the roles youth played in the organization. The vision of the organization affected the type of skills that the young people should acquire. As seen in figure (2) the youth in YA were expected to be community mobilizers. The organization was based on community organizing and the political party approach for community empowerment. Accordingly, the young people were provided direct skills to be involved in their local communities. They were based in their local community, and not in the cities were the Headquarter of the organization is. Hence, the type of activities that they were encouraged to participate in were all related to community empowerment and development. The political party identity was clear in the type of interventions that they had in the community especially during 
the Second Intifada period, when in villages, where the youth centers are based, were totally separated from the cities and accordingly they had to work on issues with regards to collective economic empowerment. The interventions led by young people for their community for projects such as food for work was changed toward going back into the cultivating the land and to develop a community resiliency and sustainability. This was in line with the political party affiliated with the organization that was used during the late 1970's and during the First Intifada period. The organization strategies for community empowerment stemmed out from its original party approach which related both economic development with community empowerment. Accordingly, when intervening during the Second Intifada their programs focused on joining the two components in programs implemented. Further, as identified as a grassroots organization, the youth were directed towards building alliances for their work on a local community level, to provide support for other $\mathrm{CBO}$ s working on the ground. According to the youth in the organization we notice

As for the YRA, the organization was more interested in creating young journalist, and with the start of the Second Intifada they expanded the skills into using media to mobilize for issues raised by the community. The youth in this organization were trained to take leadership of the programs but they were trained more on working on organizational leadership, in which they work on running the daily work of the organization, and the institutional leadership was kept to the founders of the organization. Institutional leaders are the leaders that focus on building the strategic direction of the organization, building the culture and identity of the organization. And accordingly the skills provided for young leaders were related to being program managers and practicing journalists.

As for Engage, the third organization, which is identified as a youth led organization, a core group of leaders needed to be trained to take a larger role in the organization, as the organization was identified as a youth led organization. Youth needed to be able to manage an organization's daily activities, negotiating with donors and policy makers, fundraise, and implement programs. For example, when Engage found itself as a youth led organization and not as UNDP supported program, the youth leaders main strategy was to direct their efforts to fundraising, and ensuring that they meet the donors' organizations standards for funds. This decision made by youth was encouraged by the founder of the organization who was affiliated with donor's organization.

Although the level of participation of young people in each of the organizations varied, yet the concentration of power was still in the hands of the founders. In the three cases the seniority of the founder was considered for the efforts they invested in the organization and the realization of the founders ability to mobilize resources.. Accordingly, voicing of disagreement was seen by youth as a way of undermining these efforts (Mohamad, 2011). At YA the founder was seen to have a great history in community mobilization and the party which is making it difficult to disagree with. As for YRA, in addition to her access to financial resources and being trusted by donors, for young leaders and board members knowing that she was not only the founder, but the owner of the idea it was difficult to divert from her vision to the organization, she was seen to be the owner of the idea. At Engage, in addition to the role played by the founder in mentoring the core group of youth leaders, he had a great network that over the years channeled the financial resources towards the organization, and ensured a good connection with donors and decision makers. The founder realized that he has the control over resources channeled towards the organization, and according to him "After 10 years they already developed and they are doing 
good things and are bringing great ideas, but the moment they do something I don't like I will close this organization, we both know that I can" This quotes presents not only the perception of power between founders and youth leaders, it also presents a type of pressure on decision making that is made by young people in a youth led organization. With this we can notice that although the structure is supposed to bring the highest participatory form for young people. Yet it I become limited especially with the limited control and access for young people to resources.

The position of young people also varied based on the number of years they spent with the organization, the first cohort of youth leaders in the organization, had better position in the organization than later youth joining the organization. This can be related to the fact that they spent much time with the founders when the three organizations were smaller and during establishment phase which allowed them to develop stronger networks among themselves; they have more ownership of the organization especially that they were part of the establishment phase. During this period the mentorship process focused on one-to-one interaction between youth and adults and as a result provided a safe place for young people to voice their concern. With organizations getting bigger, and institutionalized, mentorship process got weaker, and instead training and capacity building too $\mathrm{k}$ place through training and workshops.

Hence, by assigning youth to positions in the organizations whether as coordinators or second line management they were allowed to be included as collaborators and leaders rather than as objects in different aspects of the organization's life (Wheeler, 2000). Both Polletta (2002) and Wheeler (2000) talks about how organizational structures impact the type and level of participation. Nevertheless, this participation varied from one organization to another depending if youth were allowed to reach the highest level of management of the organization, which includes the board of directors and General Assembly, and the executive management.

From a youth development perspective, the three organizations had helped youth to develop the four C's described in the youth development literature as: 1) competence and interpersonal skills; 2) connection to others; 3) character building by embracing individual responsibility and community service; 4) confidence building through setting and achievement of goals (Delgado \& Staples, 2007; Watts \& Flanagan, 2007; Youniss \& Levine, 2009). In the words of Rola (2011), an YRA staff member and previous volunteer, we can see the above values reflected as she describe how they worked:

"It was easy to talk to management at any time, despite the fact that the newspaper needed to be reviewed by the management; still we could discuss all aspects of it, and be part of the decisions. The atmosphere was friendly and we were mentored by older young people, but still we felt that it is a home for us that we loved to be in".

In addition to the expectation of the organizations for the roles played by the young people the approach used to work with youth shaped their identity, leadership style, and the space provided. In the three organizations it was noticed after interviewing the youth from many cohorts that the three organizations shifted from mentorship relationship to training youth through workshops. One of the interesting results of this research was related to how organizations succeeded and failed in developing leadership among young people is with the approach they used. The first cohort capacity building took place through direct mentorship of founders to the leaders, with that the first cohort gained more than skills to play their roles. Their identity was shaped, and feeling of belonging to the organization, and their world view. 
Yet with the expansion of the work of the three organizations it is noticed that most of the training of young people started to take place through training workshops. The training workshops became the approach in which the organizations utilized for training young people. Young leaders started to have fewer roles in running even the organizations daily life. With that the skills and capacities they gained became less. Further, the access to financial resources impacted the type of training that was accessed by youth in the three organizations. YA was the least organization to access financial resources, accordingly providing training for its youth through various programs was limited.

\section{Conclusion}

To conclude, similar to other countries of the world, starting point of engagement, organization's type, relation across generations shaped the youth skills and approach for civic engagement. Not only the starting point played an essential role in deciding the structure in which young people are joining, but also it presents a context that shapes the opportunities of engagement for young people. The first cohort of youth leaders was mainly involved in NGOs structures; their engagement was mostly at organization management level, and working through projects. The youth became part of an institutional structure that provides the services for youth sector. Further, the interaction with founders and type of programs that they joined shaped their identity, skills and world view. By doing things in a specific way they developed their habitual processes.

Youth position and approach for being active citizens cannot take place without thinking jointly with youth about how the various agents are impacting them, and what kind of citizen we want, and most importantly is what type of contract the youth see themselves joining. This paper I did not look into issue of gender, locality, and education as factors deciding the youth socialization, yet they are issues to consider for further analysis for the socialization process of the Palestinian youth over time. 


\section{References}

CAMINO, Linda (2000): "Youth-Adult Partnerships: Entering New Territory in Community Work and Research", Applied Developmental Science, 4, pp. 11-22. http://dx.doi.org/10.1207/S1532480XADS04Suppl_2

CAMINO, Linda (2005): "Pitfalls and promising practices of youth-adult partnerships: An evaluator's reflections", Journal of Community Psychology, 33/1, pp. 75-85.

http://dx.doi.org/10.1002/jcop.20043

CAMINO, Linda and ZELDIN, Sheperds (2002): "From Periphery to Center: Pathways for Youth Civic Engagement in the Day-To-Day Life of Communities", Applied Developmental Science, 6/4, pp. 213-220. http://dx.doi.org/10.1207/S1532480XADS0604_8

MACNEIL, Carole (2006): "Bridging generations: Applying adult leadership theories to youth leadership development”, New Directions for Youth Development, no 109, pp. 27-43.

COLLINS, John (2004): Occupied by memory the Intifada generation and the Palestinian state of emergency, New York, New York University Press.

DELGADO, Melvin and STAPLES, Lee (2007): Youth-Led Community Organizing : Theory and Action, Cary, NC, USA, Oxford University Press, Incorporated.

DIMAGGIO, Paul and Powell, WALTER (1983): "The Iron Cage Revisited: Institutional Isomorphism and Collective Rationality in Organizational Fields", American Sociological Review, 48/2, pp.147160. http://dx.doi.org/10.2307/2095101

FLANAGAN, Constance (2013): Teenage Citizens. The Political Theories of the Young, Harvard University Press, Cambridge.

FREEDMAN, Marc (1993): The kindness of strangers : adult mentors, urban youth, and the new voluntarism, San Francsco, Jossey bass.

GAMBONE, Michelle; CAO Y, Hanh; LEWIS-CHARP, Heather; SIPE, Cynthia and LACOE, Joana. (2006): "Youth, Organizing, Identity-Support, and Youth Development Agencies as Avenues for Involvement", Journal of Community Practice, 14(1/2), pp.235-253.

GREENWOOD, Royston, SUDDABY, Roy and HININGS, C. R. (2002), "Theorizing Change: The Role of Professional Associations in the Transformation of Institutionalized Fields", Academy of Management Journal, 45/1, pp.58-80. http://dx.doi.org/10.2307/3069285

HAMMAMI, Rima (2000): "Palestinian NGOs Since Oslo: From NGO Politics to Social Movements?", Middle East Report , 214, pp. 16-48.

HARDY, Cynthia and MAGUIRE, Steve (2008): "Institutional Enterpreneurship", in GREENWOOD, R oyston, OLIVER C., SUDDABY, Roy and SAHLIN, K (Eds.), The Sage Handbook of Organizational Institutionalism, London, SAGE Publications Ltd, pp. 198-218.

http://dx.doi.org/10.4135/9781849200387.n8 
HILAL, Jamil (2010): "The Polarization of the Palestinian Political Field", Journal of Palestine Studies ,39/3, pp. 24-39. http://dx.doi.org/10.1525/jps.2010.XXXIX.3.24

JAD, Islah (2004): "The NGO-isation of Arab Womens Movements", IDS Bulletin, 35, pp. 34-42. http://dx.doi.org/10.1111/j.1759-5436.2004.tb00153.x

JAD, Islah (2007): “NGOs: between buzzwords and social movements", Journal Development in Practice, 17/4, pp. 622-629.

JARRAR, Alam (2005): “The Palestinian NGO Sector: Development Perspectives”, Palestine - Israel Journal of Politics, Economics \& Culture, 12/1, pp.43-48.

KANAANA, Sharif (1993): "The role of women in Intifada legends", Journal Contemporary Legend, 3, pp.37-61.

KLANDERMANS, Bert (1989): Organizing for change: social movement organizations in Europe and the United States, Greenwich, Conn. [u.a.] : JAI Pr.

KLATCH, Rebecca (1999): A generation divided: the new left, the new right, and the 1960s, Berkeley, University of California press.

MCADAM, Dough (1992): "Gender as a Mediator of the Activist Experience: The Case of Freedom Summer", American Journal of Sociology, 97/5, pp. 1211-1240.

http://dx.doi.org/10.1086/229900

MEYER, David (2003): "Political Opportunity and Nested Institutions", Social Movement Studies, 2/ 1, 17-35. http://dx.doi.org/10.1080/1474283032000062549

MEYER, David and MINKOFF, Debra (2004): "Conceptualizing Political Opportunity", Journal Social Forces, 8/24, pp. 1457-1492.

MISCHE, Ann (2008): Partisan Publics: Communication and Contention across Brazilian Youth Activist Networks, Princeton: Princeton University Press.

MORRIS, A. D. and STAGGENBORG, S. (2007): "Leadership in Social Movements", The Blackwell Companion to Social Movements, Blackwell Publishing Ltd., pp. 171-196.

POLLETTA, Francisca (2002): Freedom Is an Endless Meeting. Democracy in American Social Movement, Chicago, Chicago University Press.

RABAH, J. (2009): Mappying of Organizations Working with Youth in the oPt, Ramallah: United Nations Development Program.

RAHAL, Omar (2006): Youth, organization, structures, programs, and youth clubs, Ramallah: Sharek Youth Forum.

RAHAL, Omar (2010a): Concerns of youth community development and the right to participate, 
Ramallah, Human Rights and Democracy Media Center "SHAMS".

RAHAL, Omar (Ed.) (2009): Alshabab Qadaya w Mawdoat, Ramallah, Palestine: Center for Human Rights and Democratic Participation.

RAHAL, Omar (Ed.) (2010b): Youth, Community Development and good Governance, Ramallah, Palestine: Human Rights and Democracy Media Center.

VERBA, Sidney; SCHOLOZMAN, K. Lehman and BRADY, Henry (1995): Voice and Equality: Civic volunteerism in American politics, Cambridge, MA: Harvard University Press.

WASHINGTON, Boal and DAVIS, J. N. (2008), "Institutional Leadership: Past, Present, and Future" in GREENWOOD, Royston; OLIVER, Cynthia, SUDDABY, Royston and SAHLIN, Kerstin (Eds.), The SA GE Handbook of Organizational Institutionalism, London, SAGE Publications Ltd, pp. 721-737. http://dx.doi.org/10.4135/9781849200387.n31

WATTS, Roderick and FLANAGAN, Constance (2007): "Pushing the envelope on youth civic Engage ment: A developmental and liberation psychology perspective", Journal of Community Psychology, 35/6, pp. 779-792. http://dx.doi.org/10.1002/jcop.20178

WHEELER, Wendy (2000): "Emerging Organizational Theory and the Youth Development Organization", Journal of Applied Developmental Science, 4, pp.47-54.

http://dx.doi.org/10.1207/S1532480XADS04Suppl_6

WHITTIER, Nancy (1997): "Political generations, micro-cohorts and the transformation of social movements", American Sociological Review, 62/5, pp. 760-778.

http://dx.doi.org/10.2307/2657359

WYN, Johanna and WOODMAN, Dan (2006): "Generation, Youth and Social Change in Australia", Journal of youth Studies, 9/5, pp.495-514.

http://dx.doi.org/10.1080/13676260600805713

YATES, Miranda (1999): Roots of civic identity: international perspectives on community service and activism in youth, Routledge, Cambridge.

YIN, Robert (1994): Case study research: design and methods, Thousand Oaks, Sage Publications.

YOUNISS, James and LEVINE, Peter (2009): Engaging young people in civic life, Nashville, Tenn, Vanderbilt University Press.

YOUNISS, James; BALES, Susan; CHRISTMAS-BEST, Verona; DIVERSI, Marcelo; MCLAUGHLIN, Milbery and SILBEREISEN, Rainer (February 2002): "Youth Civic Engagement in the Twenty-First Century", Journal of Research on Adolescence, 12/1, pp. 121-148.

http://dx.doi.org/10.1111/1532-7795.00027

ZELDIN, Sheperd; PETROKUBI, July and MACNEIL, Carole (2008): "Youth-Adult Partnerships in Decision Making: Disseminating and Implementing an Innovative Idea into Established Organizatio ns and Communities", American Journal of Community Psychology, 41/3, pp. 262-277. 
ZIMMERMAN, Kristen (2007): "Making Space, Making Change: Models for Youth-Led Social Change Organizations", Journal Children, Youth \& Environments, 17/2, pp. 298-314

\section{Interviews:}

Ala (2011). Interview with Ala. Ramallah- Palestine.

Amal (2011). Interview with Amal. Ramallah-Palestine.

Dalal (2011). Interview with Dalal. Ramallah-Palestine.

Mohamad(2011). Interview with Mohamad. Ramallah-Palestine.

Mona (2011). Interview with Mona. Ramallah-Palestine.

Mutaz (2011). Interview with Mutaz. Ramallah-Palestine.

Reyad (2011) Interview with Reyad. Ramallah-Palestine.

Rola (2011). Interview with Rola. Ramallah-Palestine. 
